VOL. 01 NO. 01, JUNE 2019

\title{
Quizlet: A Digital Media for Learning Informatics Terms
}

\author{
DURRATUL HIKMAH \\ Universitas Nurul Jadid Paiton Probolinggo \\ durrohhikmah@unuja.ac.id
}

\begin{abstract}
Learning informatics terms in English conventionally make students learn passively and concern with the lecturer being the controller of the learning environment. Besides, this method regards the students as having 'knowledge holes' that need to be filled by information. Hence, the learning process becomes passive and boring. This paper proposed the using of Quizlet as a digital media in introducing Informatics terms to Informatics students of Nurul Jadid University Paiton Probolinggo. The learning activity is designed using the available menus in Quizlet application such flash cards, learn, speller, and test. By this method, the learning process is interesting because the learners are easy to learn the material and know the spelling error that generally occurs in studying foreign language. The result of this paper showed that Quizlet was more interactive and provided the learners with instant feedback as they go through the activities within a set of terms.
\end{abstract}

Keywords: Quizlet, Informatics terms.

\section{INTRODUCTION}

In Indonesia, English is taught from primary to high level of education. At the high level, English is a compulsory subject for every department. One of its reasons is because many syllabi in science and engineering are written in English. Second is English is the dominant language in science, and most of researches and studies are written in it as well. English is taught in order to make all the material more accessible to international students. Besides, almost all the latest technology tools use English in their use, and its tutorial book is often used in English. Therefore, this is the reason for the importance of learning English. By learning English, of course it will greatly help us in understanding.

As English grows more, technology also uses English as its most language. It began with the proliferation of technology companies in a country whose first language is English, America, so that almost all the most commonly used programming languages are rooted in English vocabulary. Moreover, most IT documentation and technology research are published in English than other languages. As a result, technology workers with low English proficiency have difficulty accessing the main resources in their fields. Good English skills and internet connections allow people to access more knowledge, find global collaborators, and share their ideas with wider viewers. More than half of the ten million most visited websites on the internet are presented in English. Inevitably, cutting-edge research and innovation in technology requires language facilities. It can be proven that understanding technology can also encourage English proficiency. The use of internet provides a wider exposure to English. This is a cycle of self-reinforcement, English provides access to a broader range of information, and international exposure builds English language skills. Therefore, a higher level of internet access correlates with higher English proficiency will produce great human resources in the field of technology.

Informatics students of Nurul Jadid University find difficulties in learning technology terms in English for the first time. The problem arises when 1) some students do not understand the meaning of the terms in computer menus, 2) some other students understand the meaning but are still wrong in pronunciation, and 3) and others ignore learning those English terms. Learning informatics terms in English conventionally make students learn passively and concern with the lecturer being the controller of the learning environment. Besides, this method regards the students as having 'knowledge holes' that need to be filled by information. Therefore, English lecturer has to be responsible for trying to find interesting method in introducing foreign terms in informatics. 


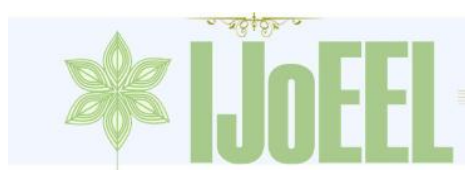

VOL. 01 NO. 01, JUNE 2019

Some researches had conducted interesting methods in lecturing foreign terms. The first research, conducted by (Petty, 1967) analyzed eighty different methods in teaching vocabulary. The result was the use of various methods in teaching vocabulary was more effective than standing on one teaching method. Then, (Sitompul, 2103) investigated whether flashcards or word list could help students' vocabulary mastery and to discover the students' responses toward both strategies in learning English vocabulary. The result of the study suggested that flashcards were more effective in helping students mastering vocabulary. Moreover, students' responses toward the use of flashcards were positive. By flash cards, the students easily remember the words list and are motivated in learning English. Both researches had attempted to give solution for teaching foreign vocabularies to students. However, as informatics develops, teacher starts to think that effective traditional methods spend much time. Those effective methods can be developed by collaborating creative traditional method with digital technology features. Puspita (Puspita, 2010) had attempted to collaborate it by creating a puzzle game for introducing informatics terms using macromedia flash 8 . This game can be an interesting facility in learning vocabulary. However, this game has only one menu, it is guessing word form jumbled letters without any definition and examples in a sentence.

Technology has become one of the most powerful drivers of acceptance of English. Digital equipment and platforms provide exposure to various native English sources to individual learners and free them from a top-down teaching approach. In many instances, technology can provide higher quality English language training than locally available. In theory, the increasing availability of fast cellular connections and the diversification of general and private English training should make it easier for adults to adjust their learning experience and improve their English language skills outside of formal schooling. Progress in the fields of artificial intelligence, virtual reality, and other new technologies can create a new era of digital training that is more interactive and relevant. But in practice, many online courses are constrained by low acceptance and high levels of stop learning. In order for English language training with technology support to reach its full potential, providers need to involve students with attractive design strategies and direct online teaching.

This study proposed Quizlet as digital media in introducing Informatics terms to Informatics students of Nurul Jadid University in English learning. This media provides more menus than just flash cards. Quizlet is a free website providing learning tools for students, including flashcards, spelling, learn, test, scatter and space race. Essentially, the main function of Quizlet is indeed used to develop linguistics skill, especially in enriching vocabularies. However, Quizlet can be used to train four language skills including listening, speaking, reading, and writing. In listening, users can exercise their skill by listening to audio that consists of definition of a word in speller. Besides, users can exercise their pronunciation through flashcards, while reading skill is trained in menu scatter and space race. Writing skill is used in typing the answers in learn, speller, test, and space race. However, this research takes only four menus of quizlet, they are flash card, learn, spell, and test. It aims at students can get feedback as go through the activities within a set of terms. Therefore, this study investigate the use of Quizlet as a digital media in introducing Informatics terms to informatics students in English leaning and their respond toward this media.

\section{B. Literature Review}

\section{Learning Vocabulary}

Vocabulary is important material in mastering a certain language. It enables the learners to understand what they read and hear, and it's also essential for their own production of language. Mastering many vocabularies not only help them to describe more concepts but also it foster their ability in producing appropriate words in different context.

There have been numerous approaches in teaching language. Each teacher has slightly different teaching style, some of them focus on grammar, and some others focus on developing four skills. However, without learning vocabulary, none of these cannot exist and importantly no communication can happen 


\section{VOL. 01 NO. 01, JUNE 2019}

(Kálecký, 2016). According to Brown, the best internalization of vocabulary comes from encounters (comprehension or production) with words within the context of surrounding discourse. If the teachers attend the vocabulary within a communicative framework in which items appear, students will associate new words with a meaningful context to which they apply (Brown, 2007).

\section{Quizlet}

Dealing with the increasing adoption of the Internet as a learning network and also supported by the existence of more affordable mobile devices, students throughout the world are increasingly easy to learn anywhere. Similarly, some startup companies are competing to build educational platforms that make it easy for everyone to use. Quizlet Startup was founded in 2005 when a teenager named Andrew Sutherland wanted to learn French. This boy creates his own learning tool and then shares it with his classmates. Gradually this learning pattern is favored by many students throughout the world. Nearly 25 percent of high school students in America have used this platform. Quizlet provides learning tools for educators to build courses and prepare learning materials, while creating a curriculum for elementary students to college students. Everyone who wants to learn something can rely on technological innovations from Quizlet, including learning foreign languages, fitness courses, and others. The excellence for students is they can connect with educators through websites and mobile devices.

The use of computer and digital technology in learning process are increasingly in demand. One of learning media that can be accessed via mobile and internet is Quizlet. Quizlet is a free mobile and web-based education providing learning tools for students, including flashcards, speller, learn, test, and space race (Kálecký, 2016). Essentially, the main function of Quizlet is indeed used to develop linguistics skill, especially in enriching vocabularies. However, Quizlet can be used to train four language skills including listening, speaking, reading, and writing. In listening, users can exercise their skill by listening to audio that consists of definition of a word in speller. Besides, users can exercise their pronunciation through flashcards, while reading skill is trained in menu scatter and space race. Writing skill is used in typing the answers in learn, speller, test, and space race. It aims at students can get feedback as go through the activities within a set of terms.

\section{Research Methodology Research Design}

This study is descriptive qualitative. It describes how implementing Quizlet in introducing informatics terms to students and their responses toward this media. This study aims at describing natural phenomenon as in line with Putranto's research (Pusparini, $\mathrm{Pd}, \& \mathrm{Pd}, 2013$ ) that a study that investigate a natural phenomenon which is founded during learning process without any statistical calculation is called descriptive qualitative.

\section{Participants}

In this study, the researcher just sat in the corner of the class while she observed the learning and teaching process. The researcher observed several points, they were: 1) teaching-learning process by using Quizlet, and 2) the students' responses toward the media. This study took the third semester of Informatics students, academic year 2018/2019. The students at that class have different ability in recognizing foreign vocabularies. Some students do not understand the meaning of the terms in computer menus, some other students understand the meaning but are still wrong in pronunciation, and others ignoring those English terms.

This research focuses on 80 female students in Informatics department. These students were divided into three classes, A, B, and C. A class consisted of 26 students; B class had 29 students, and C-class had 25 students. Since this research was conducted in Islamic boarding University, not all students were allowed to have smartphone and computer. Only those who do not live in Islamic boarding University can operate this game via smartphone. Therefore, the students in every class were divided into some groups. Every group should have one, two, or more students who can operate smartphone to access Quizlet. 


\section{Research Instrument}

The research instrument of this study is doing observation and questionnaire. Observation is one of the gathering techniques that is done by researcher to find out the important events or fact which are related to the research. Besides, by doing observation, the researcher will be able to know the real situation in the classroom and the characteristics of each student. The researcher observed the subject, class condition, teaching method, teaching-learning process, and students activities during the use of Quizlet in introducing informatics terms. It was held on September 2018. While questionnaires were given to students to investigate their participation in the teaching-learning process, their feeling about the class, and their responses toward the media.

\section{Findings}

Based on the observation conducted during learning informatics terms process in English subject by using Quizlet, this media can be an interactive media for students. It can be proven from students activities on each Quizlet menu. During the learning process, the students were divided into some groups so they could work together to find the answer for each questions. Every group was required to compete in giving the answer.

\section{The Use of Quizlet in Introducing Informatics Terms}

\section{Flashcards}

Flashcards is the easiest menu in quizlet. This menu is same as the traditional flashcards, it has question in one side and has answer in another side of card. In figure 3.1, it shows a definition of thing than it demands the students to guess the term of it. In order to know whether the answer is right or wrong, the user can click the card, so it will show the right answer.

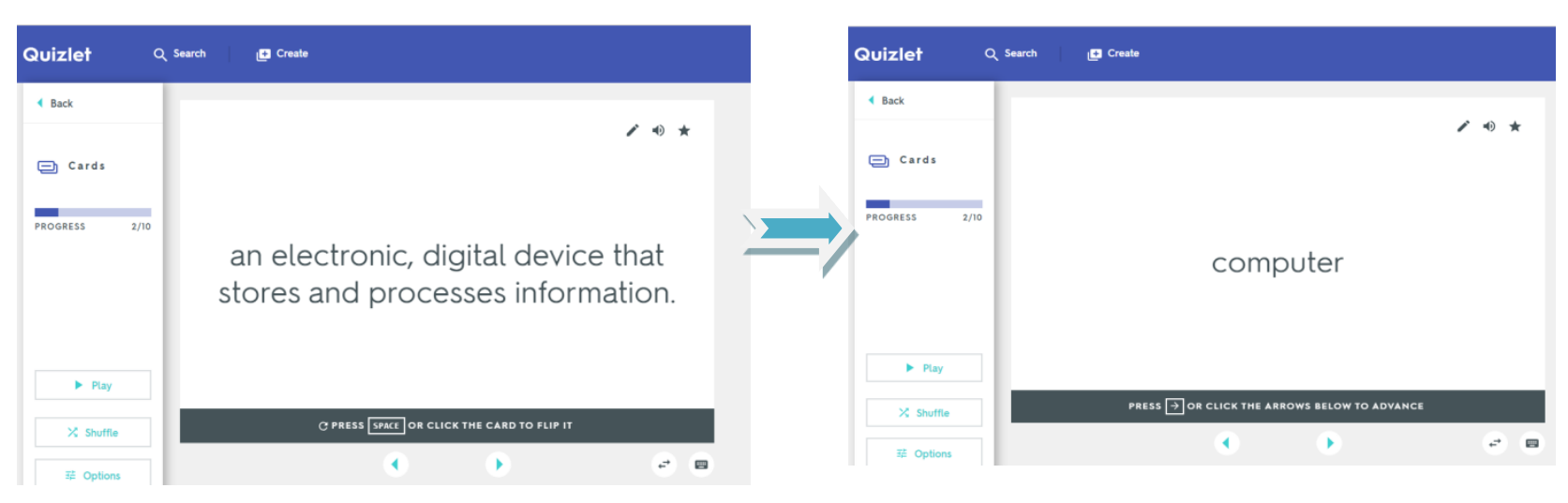

Figure D.1 flashcards. A screenshoot of quizlet.com.

This menu measures the students' knowledge on informatics terms by guessing the term. The teaching model that match with flashcards is guessing words by dividing the participants into several groups (Aribowo, 2015). Hence, the students in each class are divided into several groups and each group competes quickly to guess the answer. At firstly, for the first until third question, students were confused and less confidence to answer. Only one group looked very active guessing the answer. But fortunately, other groups were motivated to guess the answer of the next card. This menu could help the students in memorizing the informatics term through independent learning experience. 


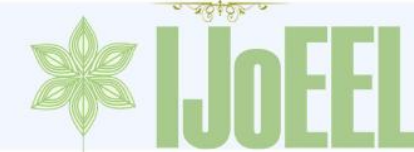

\section{Learn}

\section{VOL. 01 NO. 01, JUNE 2019}

In this menu, every group typed the answer of the available definition as shown at figure 3.1. After typing the answer, students could recognize whether the answer is right or wrong (as shown at figure 3.2 and 3.3). Then, automatically the score was displayed. This menu trains the student to write the foreign term correctly. By this menu, the students directly obtained instant feedback as they had done a series of questions that help them in comprehending the learning subject.

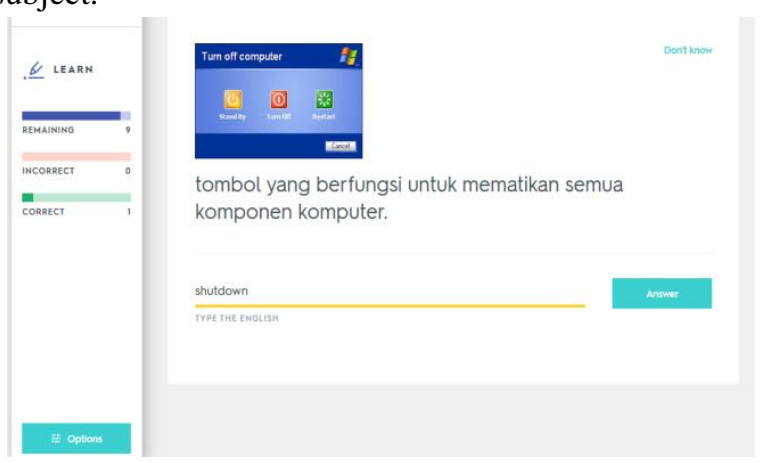

Figure D.2 Learn- a key to shut down the computer. A screenshot of quizlet.com

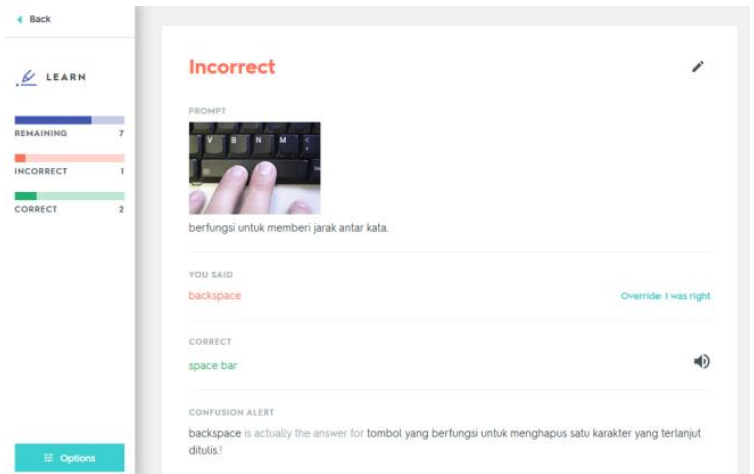

Figure D.3 Incorrect answer. A screenshoot of quizlet.com

Since this menu instructs the player to type the answer, students in group operated quizlet via their own smart-mobile. Each group was supposed to delegate a person owning smart-mobile to join the quizlet class which had been created by the lecturer. They only had a chance to guess the answer. Whether the answer is incorrect or correct, they should continue to play the game without replaying from the first question.

These questions are started by the easy one. When the player could answer easily, they would get harder question. After finishing this menu, players were able to know the result of game directly. And the lecturer as the administrator calculated the result point of each group. The higher score was the winner. By this menu, students were able to remember the vocabularies and recognize the spelling of the words.

\section{Spell}

In spell menu, the students listened to the terms spoken by the media, then they were demanded to type the result of the hearing with the correct spelling. 
VOL. 01 NO. 01, JUNE 2019

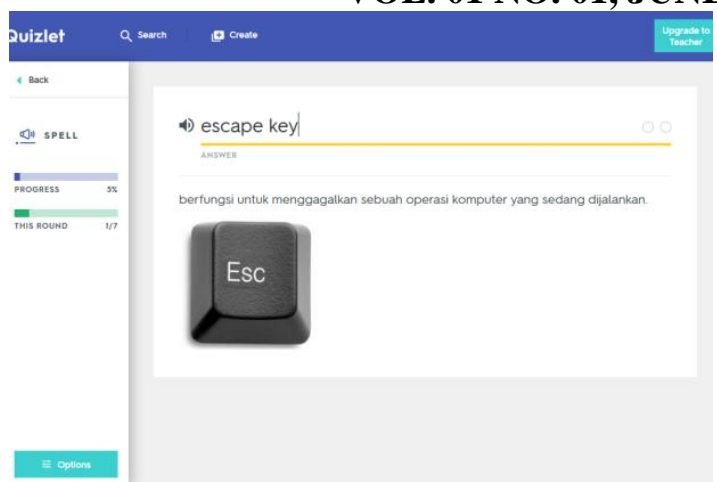

Figure D.3 Spell- escape key. A screenshoot of quizlet.com

This menu was the most exciting menu in the class. On this occasion, each group was given several papers. Then they listened to the terms spoken through this application. After that, each group wrote the result of hearing with the correct spelling (Figure 3.3). They competed quickly to write and submit it to the lecturer's desk. The winner was determined from the fastest group and has the right answer. From this menu, students could find out the pronunciation of Informatics terms correctly.

\section{Test}

This menu provides three method of question, it is writing the answer, multiple choice, and true/false. There are 10 questions in it, they are three questions for written questions, three matching questions, two multiple choice questions, and two question for true/false as shown in figure 3.4.

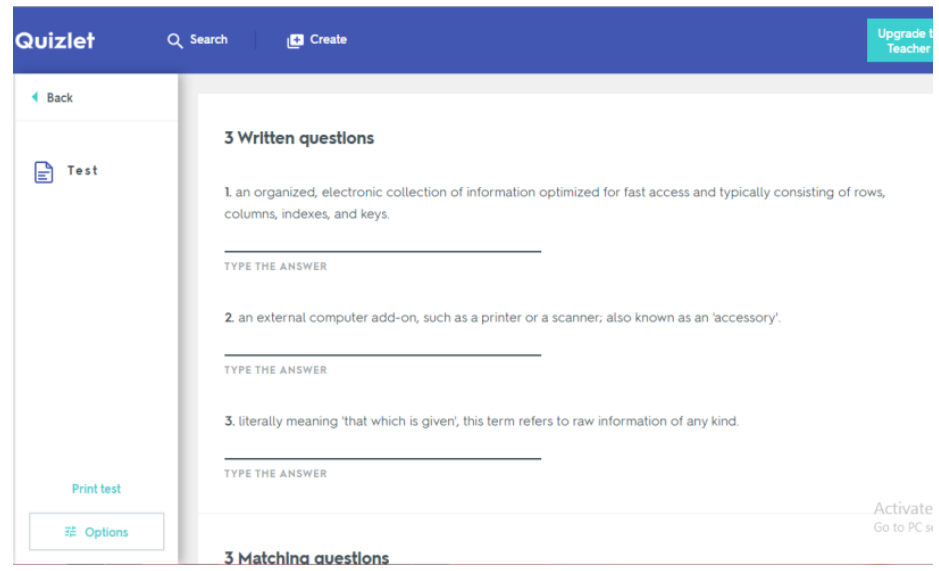

Figure D.4 Test. A screenshoot of quizlet.com

In this menu, students turned to use their own smart-mobile to answer the question. The instruction was similar to Learn menu; it required each group to delegate one person with one smartphone to answer the question in certain time. Even though it only needed one smartphone, they still could work together to answer the questions. The higher score decided the winner.

\section{Students' Responses}

Questionnaire was used in reporting students' responses upon this media. It was given to 80 students that are divided into 3 classes. The questionnaire uses Ghuttman scale with two alternative answers. There are 5 questions for students. Here is the recapitulation of students' responses on this media. 
VOL. 01 NO. 01, JUNE 2019

Table D.1 Students' responses on learning media

\begin{tabular}{|c|c|c|c|c|c|}
\hline \multirow{2}{*}{ No. } & \multirow{2}{*}{ Indicator } & \multicolumn{2}{|c|}{ Responses } & \multirow{2}{*}{ Total } & \multirow{2}{*}{$\begin{array}{l}\text { Percentage of } \\
\text { "Yes-answer" }\end{array}$} \\
\hline & & Yes & No & & \\
\hline 1. & The interest on learning media & 80 & - & 80 & $100 \%$ \\
\hline 2. & $\begin{array}{l}\text { The conformity of quizlet with } \\
\text { learning topic }\end{array}$ & 79 & 1 & 80 & $98.75 \%$ \\
\hline 3. & The clarity of instruction & 78 & 2 & 80 & $97.5 \%$ \\
\hline 4. & $\begin{array}{l}\text { The ability to encourage students' } \\
\text { curiosity. }\end{array}$ & 80 & - & 80 & $100 \%$ \\
\hline 5. & $\begin{array}{l}\text { The ability to increase students' } \\
\text { learning motivation. }\end{array}$ & 79 & 1 & 80 & $98.75 \%$ \\
\hline
\end{tabular}

From the table D.1, it can be seen that all questions get "Positive Response" with a percentage of $\geq$ $70 \%$. The following is presented the percentage of student answers to each question in the form bar chart (see figure D.5).

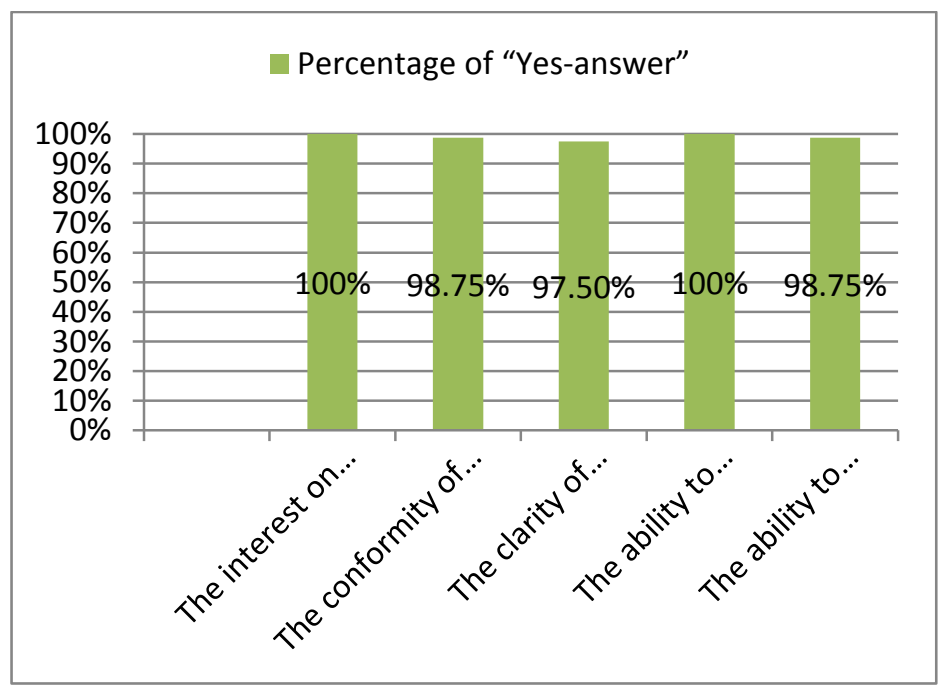

Figure D.5 Bar chart of "Yes-answer" percentage.

\section{E. Discussion}

Based on the results of the study, quizlet media can be a digital media that is very interested in informatics students to increase the mastery of foreign language vocabulary especially in the field of informatics. This media can also encourage students to learn more about informatics term. This data can be seen from the results of a questionnaire distributed to eighty informatics students.

Quizlet is a free mobile and website providing learning tools for students, including flashcards, spelling, learn, test, scatter and space race. However, this research only takes four menus of quizlet because of lack of time and means. As stated before, the participant of this research is eighty students of informatics department of Nurul Jadid Univesity. Since this University is included to an Islamic boarding school, most of the University students are Santri (students who stay in Islamic boarding school or pesantren) who are not allowed to have and operate smartphone. Fortunately there are some students who study in this university and do not stay in boarding school, so they are allowed to have, bring, and operate a smartphone. These students became the delegation of each group to operate the Quizlet. Therefore, in this research the Quizlet game was conducted both traditional and digital. In flashcard, the lecturer shows the game through slide power point and each group raise the hand up to answer. At firstly, for the first until third question, students were confused and less confidence to 
VOL. 01 NO. 01, JUNE 2019

answer. Only one group looked very active guessing the answer. But fortunately, other groups were motivated to guess the answer of the next card. This menu could help the students in memorizing the informatics term through independent learning experience. Spelling menu was also mixed in traditional and digital media. It instructed the players to write a word they heard from audio, so they had to write the answer in a paper and quickly submitted to lecturer's desk. However, in learn and test menu, the students play the game through digital media because they could directly know the result of the game. By this game, the players directly got feedback as they go through the activities in learning.

According to Piaget, the level of students' understanding of the concept of objects, names, types of animals and understanding other types of concepts cannot be done only through reading and listening to teacher explanations (Fitriyani \& Nulanda, 2017). Children need the help of more expert people so that they can complete their assignments in the right way called Vygotsky's ZPD (Zone of Proximal Development). Based on that view, a real object or visual form is needed to know and recognize the concepts learned. The right method to teach new vocabulary is to use interesting props, so students can easily get to know the new vocabulary.

Learning by using Quizlet media can help the students memorize and quickly remember the words they have learned. In addition, it effectively increases vocabulary, quizlet can also motivate and make students interested in learning (Fitriyani \& Nulanda, 2017). They pay attention to the teacher in front and focus on the flash cards given, they are also enthusiastic about pointing their hands when given questions about the words. Brown stated Playing while learning to use flash cards will affect student affective which affect the success of learning words (Brown, 2007).

\section{F. Conclusion}

Quizlet is one of the best education websites in the world. As a supporting learning media, Quizlet gives many facilities with audio-visual. It means that students can listen to the pronunciation as they pay attention to picture in flashcard. Furthermore, as students spend a lot of time using technology, Quizlet is expected to be more enjoyable to study from because it employs devices that they are familiar with.

In this study, Quizlet was very effective media to improve students' mastery in English vocabulary, especially in informatics terms. Through this study, it had been proven that Quizlet had effectively improved students' interest in learning Informatics term in English, overcome students' boredom, created a new nonthreatening atmosphere, and raised up the students' confidence to learn English. This media got the good responses from students. They were happy playing this game; it was simply because they got feedback as they go through leaning activities.

The teaching method delivered is little example of Quizlet implementation in learning process. Hence, it is possible to have more creative and innovative ways in using Quizlet as digital media in teaching process.

\section{REFERENCES}

Aribowo, E. K. (2015). QUIZLET2: PENGGUNAAN APLIKASI SMARTPHONE UNTUK SISWA DALAM MENDUKUNG MOBILE LEARNING. In Seminar Nasional Pendidikan Bahasa Indonesia 2015 (pp. 31-38). Retrieved from https://publikasiilmiah.ums.ac.id/bitstream/handle/.../Eric Kunto Aribowo.pdf?.

Brown, H. D. (2007). Teaching by principles: An interactive approach to language pedagogy. (D. Belfiore, T. M. Cataldo, D. Dickey, L. Le Drean, \& M. Leyva, Eds.) (Fifth). New York.

Fitriyani, E., \& Nulanda, P. Z. (2017). Efektivitas Media Flash Cards dalam Meningkatkan Kosakata Bahasa Inggris, 4, 167-182. https://doi.org/10.15575/psy.v4i2.1744 


\section{VOL. 01 NO. 01, JUNE 2019}

Kálecký, R. (2016). Quizlet vs. Vocabulary Notebook: The Impact of Different Methods of Storing and Revising Vocabulary on Students' Progress, Retention and Autonomy. Masaryk University.

Petty, W. T. (1967). The state of the knowledge about the teaching of vocabulary. Sacramento, California. Retrieved from https://eric.ed.gov/?id=ED012395

Pusparini, R., Pd, S., \& Pd, M. (2013). THE IMPLEMENTATION OF STEPS CHAIN AS A TECHNIQUE TO TEACH SPEAKING PROCEDURE TEXT FOR SEVENTH GRADERS OF SMPN I SIDOARJO.

Puspita, K. C. (2010). Rancang Bangun Aplikasi Game "Puzzle Kata" Istilah Teknik Informatika Menggunakan Macromedia Flash 8. Dinamika Informatika, 4, 25-34. Retrieved from http://dinamika-informatika.upy.ac.id/?p=50

Sitompul, E. Y. (2103). TEACHING VOCABULARY USING FLASHCARDS AND WORD LIST (A Quasi-Experimental Study with Fifth Graders in One Public Elementary School in Binjai). Universitas Pendidikan Indonesia. Retrieved from http://repository.upi.edu/1700/2/S_ING_0807302_Abstract.pdf 